University of Maryland Francis King Carey School of Law

DigitalCommons@UM Carey Law

2011

\title{
William H. Sorrell, Attorney General of Vermont, et al. v. IMS Health Inc., et al. - Amicus Brief in Support of Petitioners
}

Kevin Outterson

David Orentlicher

Christopher T. Robertson

Frank A. Pasquale

University of Maryland Francis King Carey School of Law, fpasquale@law.umaryland.edu

Follow this and additional works at: https://digitalcommons.law.umaryland.edu/fac_pubs

Part of the First Amendment Commons, Health Law and Policy Commons, and the Privacy Law Commons

\section{Digital Commons Citation}

Outterson, Kevin; Orentlicher, David; Robertson, Christopher T.; and Pasquale, Frank A., "William H. Sorrell, Attorney General of Vermont, et al. v. IMS Health Inc., et al. - Amicus Brief in Support of Petitioners" (2011). Faculty Scholarship. 1369.

https://digitalcommons.law.umaryland.edu/fac_pubs/1369

This Other is brought to you for free and open access by the Francis King Carey School of Law Faculty at DigitalCommons@UM Carey Law. It has been accepted for inclusion in Faculty Scholarship by an authorized administrator of DigitalCommons@UM Carey Law. For more information, please contact smccarty@law.umaryland.edu. 
No. 10-779

\section{$\mathfrak{J n} \mathfrak{T} \mathfrak{d} \mathfrak{e}$ \\ Supreme Court of the afnited States}

WILLIAM H. SORRELL, as Attorney General of Vermont, et al.,

Petitioners,

v.

IMS HEALTH INC., et al.,

Respondents.

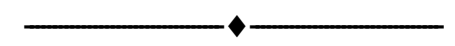

On Writ Of Certiorari To The United States Court Of Appeals For The Second Circuit

\section{BRIEF AMICI CURIAE OF THE NEW ENGLAND JOURNAL OF MEDICINE, THE MASSACHUSETTS MEDICAL SOCIETY, THE NATIONAL PHYSICIANS ALLIANCE, AND THE AMERICAN MEDICAL STUDENTS ASSOCIATION IN SUPPORT OF PETITIONERS}

MiCHAEL KeVIN OUTTERSON (Counsel of Record)

BOSTON UNIVERSITY SCHOOL OF LAW 765 Commonwealth Ave. Boston, MA 02215 (617) 353-3103 mko@bu.edu
DAVID ORENTLICHER

UNIVERSITY OF IOWA COLLEGE OF LAW \& INDIANA UNIVERSITY SCHOOL OF LAW - INDIANAPOLIS

CHRISTOPHER T. ROBERTSON

UNIVERSITY OF ARIZONA COLLEGE OF LAW

FRANK PASQUALE

SETON HALL UNIVERSITY

SCHOOL OF LAW

[Additional Counsel Listed On Inside Cover] 


\section{Additional Health Law Professors Supporting This Brief}

Timothy StoltzFus Jost

Robert L. Willett Family Professor of Law

WASHINGTON \& LEE UNIVERSITY SCHOOL OF LAW

ELEANOR D. KINNEY

Hall Render Professor of Law \& Co-Director

William S. AND Christine S. Hall CENTER FOR LAW AND HEALTH

INDIANA UNIVERSITY SCHOOL OF LAW - INDIANAPOLIS

MYLES V. LYNK

Peter Kiewit Foundation Professor of Law and the Legal Profession Faculty Fellow

CENTER FOR THE STUDY OF LAW, SCIENCE AND INNOVATION

SANDRA DAY O'CONNOR COLlege OF LaW, ARIZONA STATE UNIVERSITY

FRAN MiLleR

Visiting Professor of Law

UNIVERSITY OF HAWAII AT MANOA

Professor of Law Emeritus

BOSTON UNIVERSITY SCHOOL OF LAW

BARBARA A. NOAH

Professor of Law

Western New England College School of LaW

JORDAN K. PARADISE

Associate Professor of Law

SETON HALl UNIVERSITY SCHOOL OF LAW

VALERIE J. VOLLMAR

Professor of Law

WiLlametTe UNIVERSITy COLLEGE OF LAW

WENDY K. MARINER

Edward R. Utley Professor of Health Law

Boston University School of Public Health

Professor of Law

Boston UnIVERSITY ScHOOL OF LAW 


\section{QUESTIONS PRESENTED}

Does the First Amendment forbid Vermont from

giving physicians the freedom to keep their private medical practice information confidential? 
TABLE OF CONTENTS

Page

IDENTITY OF AMICI CURIAE ....................... 1

SUMMARY OF THE ARGUMENT.................... 2

ARGUMENT ................................................... 4

I. THE VERMONT STATUTE EMPOWERS PHYSICIANS TO PROTECT MEDICAL PRIVACY AND CONFIDENTIALITY ........

A. Data Mining Invades Medical Privacy and Confidentiality................................

B. The Prescription Confidentiality Law Fits Within The Established Framework Of State and Federal Privacy And Confidentiality Laws ..................... 10

C. Consent For Limited Purposes Does Not Justify Commercial Data Mining .. 20

II. THE SECOND CIRCUIT MISTAKENLY TREATED THE PRESCRIPTION CONFIDENTIALITY LAW AS AN UNLAWFUL RESTRICTION ON SPEECH

A. Vermont Does Not Ban Drug Advertising .............................................

B. The Vermont Law - As Amended Does Not Interfere With The "Marketplace of Ideas".

C. Medical Privacy Is A Substantial State Interest ............................................. 30

D. The Prescription Confidentiality Law "Directly Advances" Substantial State Interests 
TABLE OF CONTENTS - Continued

Page

1. Data Mining Increases Costs.......... 34

2. Data Mining Promotes Unsafe Drugs ................................................ 35

3. Section 17 Gives Vermont Physicians The Freedom To Opt Out Of Data Mining .................................... 37

E. Vermont Left This Complex Medical Decision In The Hands Of The Treating Physician ................................ 39

CONCLUSION .............................................. 42 


\section{TABLE OF AUTHORITIES}

Cases

44 Liquormart, Inc. v. Rhode Island, 517 U.S. 484 (1996)

Boehner v. McDermott, 484 F.3d 573 (D.C. Cir. 2007)

Central Hudson Gas \& Elec. Corp. v. Public Service Comm'n of N.Y., 447 U.S. 557 (1980) $25,30,31$

Cohen v. Cowles Media Co., 501 U.S. 663 (1991) .......13

Edenfield v. Fane, 507 U.S. 761 (1990). .25

IMS Health Corp. v. Rowe, 532 F.Supp.2d 153 (D. Me. 2008)

IMS Health Inc. $v$. Ayotte, 550 F.3d 42 (1st Cir. 2008), cert. denied, 129 S. Ct. 2864 (2009) ..........................................6, 31, 33, 39

IMS Health Inc. v. Sorrell, 2010 WL 4723183 (2d Cir. 2010). passim

IMS Health Inc. v. Sorrell, 631 F.Supp.2d 434 (D. Vt. 2009) 37

In re Gabapentin Patent Litigation, 312 F.Supp.2d 653 (D.N.J., 2004) 12

In re Knoxville News-Sentinel Co., 723 F.2d 470 (6th Cir. 1983) 15

Jerome Stevens Pharmaceuticals, Inc. v. Food \& Drug Admin., 402 F.3d 1249 (D.C. Cir. 2005) 
TABLE OF AUTHORITIES - Continued

Page

Lorillard Tobacco Co. v. Reilly, 533 U.S. 525 (2001) .....................................14, 15, 24, 25

Nat'l Aeronautics and Space Admin. v. Nelson, 131 S. Ct. 746 (2011) ............................................10

Olmstead v. United States, 277 U.S. 438 (1928) .......10

Thompson v. W. States Med. Ctr., 535 U.S. 357 (2002).

Trans Union Corp. v. Fed. Trade Comm'n, 245

F.3d 809 (D.C. Cir. 2001). $.30,32$

Travis v. Reno, 163 F.3d 1000 (7th Cir. 1998). .15

Va. State Board of Pharmacy v. Va. Citizens Consumer Council, 425 U.S. 748 (1976)..................25

Whalen v. Roe, 429 U.S. 589 (1977) .......................... 8

Wooley v. Maynard, 430 U.S. 705 (1977) ...................10

Constitutional Provisions

First Amendment passim

Fourteenth Amendment. .25

Statutes ANd Rules

Copyright Act, 17 U.S.C § 101, et seq .........................12

Espionage Act, 18 U.S.C. $§ 793$. .13

Fair Credit Reporting Act, 15 U.S.C. § 1681, et seq. .32 
TABLE OF AUTHORITIES - Continued

Page

Intelligence Identities Protection Act, 50

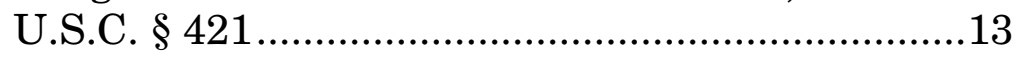

Lanham Act, 15 U.S.C. $\S 1051$, et seq ........................13

Privacy Act, 5 U.S.C. 552 ........................................13

Video Privacy Protection Act of 1988, 18 U.S.C.

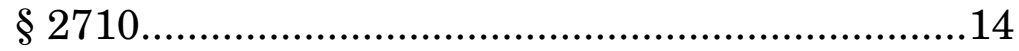

2008 Vt. Acts \& Resolves No. 89, § 3 ......................27

Health Insurance Portability and Accountability Act of 1996, Pub. L. No. 104-191.......................... 5, 33

Genetic Information Nondiscrimination Act, Pub. L. No. 110-233, 122 Stat. 881 (2008) ................5

Vermont Patient Privilege Statute, Vt. Stat.

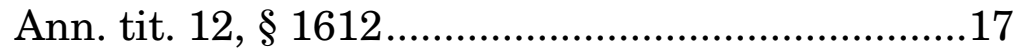

Vt. Stat. Ann. tit. 12, § 1612(a) ................................22

Vermont Patient Bill of Rights, Vt. Stat. Ann. tit. 18, § 1852(7) ................................................17

Vt. Stat. Ann. tit. 18, § 1852(a)(7) ............................22

Vermont Prescription Confidentiality Law, 2007 Vt. Acts \& Resolves No. 80, § 17 (2007) .............................................. $4,15,22,28,30$

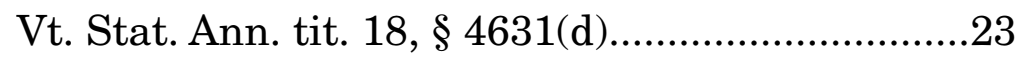

Vt. Stat. Ann. tit. 18, § 4631(e)..............................23

Vt. Stat. Ann. tit. 18, § 4631(e)(5)-(6) .....................22

Vt. Stat. Ann. tit. 18, § 4631(f) ........................27, 29

Vermont Nursing Home Bill of Rights, Vt. Stat. Ann. tit. 33, § 7301................................................17 
Federal Regulations:

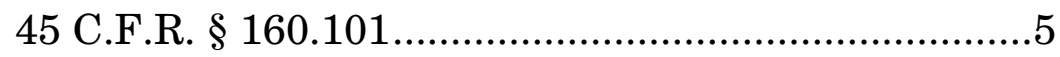

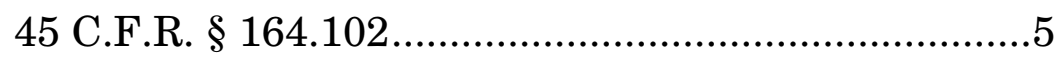

OTHER AUTHORITIES:

Aaron S. Kesselheim, et al., The Rise and Fall of Natrecor for Congestive Heart Failure: Implications for Drug Policy, 25 Health Affairs 1095 (2006)

Aaron S. Kesselheim \& David Studdert, Whistleblower-Initiated Enforcement Actions Against Health Care Fraud and Abuse in the United States, 1996 to 2005, 149 Annals Int. Med. 342 (2008).

Aaron S. Kesselheim \& Jerry Avorn, The Role of Litigation in Defining Drug Risks, 297 JAMA 308 (2007). .36

Andrew Beckerman-Rodau, Prior Restraints and Intellectual Property: The Clash Between Intellectual Property and the First Amendment from an Economic Perspective, 12 Fordham Intell. Prop. Media \& Ent. L.J. 1, 5 (2001)

Ashley Wazana, Physicians and the Pharmaceutical Industry: Is a Gift Ever Just a Gift?, 283 JAMA 373 (2000). 
C. Seth Landefeld \& Michael A. Steinman, The Neurontin Legacy - Marketing Through Misinformation, 360 New Eng. J. Med. 103 (2009). .36

Chad Terhune, They Know What's In Your Medicine Cabinet, Business Week, July 23, 2008, available at http://www.businessweek. com/magazine/content/08_31/b4094000643943. htm

Charles Ornstein, Ex-Worker Indicted in Celebrity Patient Leaks Former Employee of UCLA Medical Center is Accused of Selling Data to the Media, L.A. Times, April 30, 2008.

CVS Privacy Practices Need Investigation Despite FTC Order, Pharmacist Group Says, 18 Health L. Rep. 397 (BNA) (March 2009)

Cynthia Jackevicius, et al., Use of Ezetimibe in the United States and Canada, 358 New Eng. J. Med. 1819 (2008) ....

Daniel J. Solove, Identity Theft, Privacy, and the Architecture of Vulnerability, 54 Hastings L.J. 1227, 1260 (2003).

Eric G. Campbell, et al., A National Survey of Physician-Industry Relationships, 356 New Eng. J. Med. 1742 (2007)

Eric J. Topol, Nesiritide - Not Verified, 353

New Eng. J. Med. 113 (2005) .37

Helen Nissenbaum, Privacy as Contextual Integrity, 79 Wash. L. Rev. 119, 129 (2004). 
Jonathan D. Rockoff \& Brent Kendall, Pfizer to Plead Guilty to Improper Marketing, Wall St.

J., Sept. 3, 2009

Joyce E. Cutler, Kaiser Permanente Gets $\$ 187,000$ Fine For Second Patient Privacy Violation, 18 Health L. Rep. 974 (BNA) (July 2009).

Katia Campo, et al., Physicians' Decision Process for Drug Prescription and the Impact of Pharmaceutical Marketing Mix Instruments, 22 Health Market. Quarterly 73 (2005)

Mary Anne Pazanowski, HHS Breaks New Ground With \$43 Million Penalty for HIPAA Privacy Rule Violation, 20 Health Law Reporter 277 (BNA) (Feb. 24, 2011)

Michael A. Steinman, et al., Characteristics and Impact of Drug Detailing for Gabapentin, 4 PLoS Med. 743 (2007)

Michael A. Steinman, et al., Narrative Review: The Promotion of Gabapentin: An Analysis of Internal Industry Documents, 145 Annals Int. Med. 284, 287, Table 2 (2006) .36

Michelle M. Mello, et al., Shifting Terrain in the Regulation of Off-Label Promotion of Pharmaceuticals, 360 New Eng. J. Med. 1557, 1562-63, Table 2 (2009) $.35,36$ 
Neal M. Richards \& Daniel J. Solove, Privacy's Other Path: Recovering the Law of Confidentiality, 96 Geo. L.J. 123, 180-81 (2007)...

Nicole Lurie, et al., Pharmaceutical Representatives in Academic Medical Centers, 5 J. Gen. Internal Med. 240 (1990)

Paul Ohm, Broken Promises of Privacy: Responding to the Surprising Failures of Anonymization, 57 UCLA L. Rev. 1701, 1716 (2010).

Puneet Manchanda \& Elisabeth Honka, The Effects and Role of Direct-to-Physician Marketing in the Pharmaceutical Industry: An Integrative Review, 5 Yale J. Health Policy, Law \& Ethics 785 (2005)

Ray Moynihan, et al., Selling Sickness: The Pharmaceutical Industry and Disease Mongering, 324 BMJ 886 (2002).

Rebecca Tushnet, Trademark Law as Commercial Speech Regulation, 58 S. Car. L. Rev. 737 (2007)

Resolution Agreement, February 14, 2011, available at http://www.hhs.gov/ocr/privacy/ hipaa/enforcement/examples/massgeneralra. pdf

Richard A. Epstein, Privacy, Publication, and the First Amendment: The Dangers of First Amendment Exceptionalism, 52 Stan. L. Rev. 1003, 1006 (2000) 
TABLE OF AUTHORITIES - Continued

Page

Sharon K. Sandeen, Relative Privacy: What Privacy Advocates Can Learn from Trade Secret Law, 2006 Mich. St. L. Rev. 667, 698 (2006).....

Sharona Hoffman, Employing E-Health, 19 Kan. J.L. \& Pub. Pol'y 409 (2010)

The Prescription Project, Prescription Data Mining, at 3 (Nov. 19, 2009), available at http:// www.prescriptionproject.org/tools/initiatives_ factsheets/files/0004.pdf .38 


\section{IDENTITY OF AMICI CURIAE ${ }^{1}$}

\section{The New England Journal of Medicine} (NEJM) is the oldest continuously published medical journal in the world, and has published numerous scholarly articles on, among other things, advances in drug therapy, prescription drug side effects, and the role of the United States Food and Drug Administration and the pharmaceutical industry in our health care system.

The Massachusetts Medical Society, with some 22,000 physician and student members, is dedicated to educating and advocating for the patients and physicians of Massachusetts. We publish the New England Journal of Medicine, a leading global medical journal and web site, and Journal Watch alerts and newsletters covering 13 specialties. We are also a leader in continuing medical education for health care professionals throughout Massachusetts, conducting a variety of medical education programs for physicians and health care professionals. Founded in 1781, we are the oldest continuously operating medical society in the country.

${ }^{1}$ This brief is submitted with the consent of the parties, as lodged with the Clerk per the Docket Sheets. Pursuant to Rule 37.6, counsel represent that this brief was not authored in whole or in part by counsel for any party. All expenses of amici have been borne by their own resources, without support from any party. 
The National Physicians Alliance (NPA) is a membership organization of physicians across specialties throughout the United States who seek to restore physicians' primary emphasis on the core values of our profession: service, integrity, and advocacy for our patients. We work to improve health and well being, and to ensure equitable, affordable, high quality health care for all people.

The American Medical Student Association (AMSA) is the oldest and largest independent association of physicians-in-training in the United States, with more than 33,000 members. Founded in 1950, AMSA is a student-governed, nonprofit organization representing the concerns of physicians-in-training. AMSA advocates for evidence-based rather than marketing-based prescribing practices, the removal of conflicts of interest, and global access to essential medicines.

\section{SUMMARY OF THE ARGUMENT}

As amended, the Prescription Confidentiality Law does not include any state-sponsored intrusion into the "marketplace of ideas." Vermont does not ban data mining or drug advertising, but leaves the data mining decision in the hands of the prescribing physician. The only state action here is to empower Vermont physicians with the freedom to choose privacy. 
Most Vermont physicians have not chosen to embrace data mining. Data mining offends the privacy of the physician and also permits companies to identify particular patients and communities without consent. In addition to the privacy concerns, these practices are dangerous and raise health care costs.

The Prescription Confidentiality Law is part of a larger statutory framework of state and federal laws protecting medical privacy. Federal law has carved out a special role for more stringent state medical privacy laws, protecting them from federal preemption. The First Amendment is also not a defense to violations of copyright, trade secrecy, and privacy laws.

Nor does the First Amendment require this Court to overturn the legislative determination by the elected government of Vermont, especially when the state has extensive experience as a health care payor and has left the ultimate decision to the physician.

The Amici Curiae are leading organizations representing and educating physicians and medical students. We have followed these issues carefully for a number of years. We urge this Court to agree with Vermont, and leave the data mining decision to the physicians. 


\section{ARGUMENT}

\section{THE VERMONT STATUTE EMPOWERS PHYSICIANS TO PROTECT MEDICAL PRIVACY AND CONFIDENTIALITY}

As the oldest continuously published medical journal in the world, amicus THE NEw England JOURNAL OF MEDICINE is directly interested in commercial speech issues involving medicine. The amici file this brief with no pecuniary interest in the outcome, but with a deep respect for the privacy and confidentiality of the doctor-patient relationship. The Vermont Prescription Confidentiality Law, 2007 Vt. Acts \& Resolves No. 80, § 17 (2007) ("Prescription Confidentiality Law" or "Section 17"), protects those vital interests without offending the First Amendment. App.129a-140a. ${ }^{2}$

The Respondents assert the novel claim that private companies can use and sell private health information, violating state law, without the consent of any of the individuals involved. This case isn't fundamentally an issue of commercial speech; our view as medical publishers, physicians and medical students is that data miners have wrongfully converted private health information for commercial purposes without consent. Data miners should not

${ }^{2}$ References to "App._a" are to the appendix filed with the certiorari petition; "JA_" are to the Joint Appendix filed with the Pet. Brief; and to "A-_" are to the appendix filed in the Second Circuit. 
have a First Amendment right to use or sell private health information. Put another way, intent to publish is not a defense to violation of medical privacy laws.

\section{A. Data Mining Invades Medical Privacy and Confidentiality}

The clinical encounter between physicians and their patients is the core relationship in medicine. Our laws have long recognized that the patient visit also creates private health information, often of an intimate nature. See the Health Insurance Portability and Accountability Act of 1996 (HIPAA), Pub. L. No. 104-191 (defining federal health privacy rights); 45 C.F.R. § 160.101, et seq.; 45 C.F.R. $\$ 164.102$, et seq. (HIPAA Privacy Rule), and the recently enacted Genetic Information Nondiscrimination Act (GINA), Pub. L. No. 110-233, 122 Stat. 881 (2008) (protecting individual genetic information). Few of us would want our medical records released to the public or sold for commercial exploitation without our consent.

Respondents do not deny that prescriberidentifiable medical records lay bare the intimate details of physicians' prescribing patterns for their patients. Brief for Respondent Pharmaceutical Research and Manufacturers of America, On Petition for a Writ of Certiorari, at 4, Sorrell v. IMS Health Inc., 131 S. Ct. 857 (Dec. 15, 2010) (No. 10-779) [hereinafter "PhRMA Cert. Brief"] ("For example, a pharmaceutical representative who specializes in diabetes 
medicines may use prescriber-identifiable data to identify those physicians in her region who write a significant number of prescriptions for diabetes or cardiology medications (and thus, likely to treat a large number of diabetes patients)."); Brief of Respondents IMS Health Inc., On Petition for a Writ of Certiorari, at 3, Sorrell v. IMS Health Inc., 131 S. Ct. 857 (Dec. 16, 2010) (No. 10-779) [hereinafter "IMS Cert. Brief"] (similar). Data mining gives Respondents a clear view of exactly what happens in the physician's private office with particular patients by tracking each patient with a "longitudinal" "linking code" as the "fifth P" following individual patients, JA158-60, 482-84. Data mining Respondent Verispan boasted that "patient behavior can be directly influenced" using "actual prescription fills at the patient level," JA482, 484-86. Data mining subjects physicians to "various kinds of leverage," IMS Health Inc. v. Ayotte, 550 F.3d 42, 56 (1st Cir. 2008) (upholding New Hampshire's restrictions on the use of prescriber-identifiable data), cert. denied, 129 S. Ct. 2864 (2009), including "the ability to target physicians prescribing large quantities of generic drugs, the ability to zero in on a physician's customary prescribing choices, and the ability to punish physicians who fail to display allegiance to particular brand-name drugs." Id. Section 17 directly addresses this issue. "Without question, the law restricts the flow of otherwise private information about doctors' prescribing habits and the care they provide to their patients. No party seriously disputes that." IMS Health Inc. $v$. 
Sorrell, 2010 WL 4723183, *29 (2d Cir. 2010) (Livingston, J. dissenting) (App.1a-67a).

Physicians have a legitimate interest in maintaining the confidentiality of information relating to their medical practice. At trial, Dr. Grande testified that "the privacy of patient welfare is likely to be compromised," JA327, JA326-28. Dr. Kesselheim testified that removing data mining "will help prevent inappropriate use or over prescription of drugs in patients" JA349-50. The Vermont Medical Association resolved that "the doctor-patient relationship requires confidentiality and privacy to work effectively," JA376. See also Pet. Brief, at 7-10, 46-51. This is especially true "in an era of increasing and wellfounded concern about medical privacy," Sorrell, 2010 WL 4723183, at $* 25$ (Livingston, J. dissenting). While Respondents found at least one physician who did not expect privacy, JA280, Section 17 permits that physician to opt into data mining. The law only applies to physicians who do have a reasonable expectation of privacy.

Data mining also invades the privacy of Vermont patients, supra, pp. 5-6, Pet. Brief, at 7-8. Prescription drug records are sensitive and consequential for individuals. Patients have an "interest in the nondisclosure of private information and also their interest in making important decisions independently." Whalen v. Roe, 429 U.S. 589, 600 (1977) (privacy concerns about prescription drug records). In Whalen, the Court found "no support ... for an assumption that the security provisions of the statute will be administered 
improperly." Whalen, 429 U.S. at 601 . In the present case, the record is clear that Section 17 would extend privacy protections to prescriber-identifiable data, changing existing practices in the industry.

Respondents suggest that the prescription data in question goes through a process of de-identification, despite the presence of the longitudinal tracking number. JA158-60, 482-84. Such processes may once have been trustworthy, but advances in computer science have compromised extant security techniques, "casting serious doubt on the power of anonymization" and lesser de-identification technologies. Paul Ohm, Broken Promises of Privacy: Responding to the Surprising Failures of Anonymization, 57 UCLA L. Rev. 1701, 1716 (2010). These problems are especially acute in rural settings. In Vermont, "in small communities identifying a drug prescription can equal the release of the individual's diagnosis." JA377. Data mining exposes a patient's prescription history, and thus, their underlying medical conditions, to publication and exploitation, allowing companies to match prescriptions with specific patients. JA158-60, 482-84. This is a real concern, since

insurance giants have ready access to applicants' prescription histories. These online reports, available in seconds from a pair of little-known intermediary companies at a cost of only about $\$ 15$ per search, typically include voluminous information going back five years on dosage, refills, and possible medical conditions. The reports also provide a numerical 
score predicting what a person may cost an insurer in the future.

Chad Terhune, They Know What's In Your Medicine Cabinet, Business Week, July 23, 2008, available at http://www.businessweek.com/magazine/content/08_31/ b4094000643943.htm. Nor is this an isolated problem. "Two-thirds of all health insurers are using prescription data - not only to deny coverage to individuals and families but also to charge some customers higher premiums or exclude certain medical conditions from policies ... ". Id.

Vermont also has a substantial interest in the medical privacy of communities. Even absent specific patient identification, the Respondents are able to know the diagnoses and treatment plans for each physician's group of patients. PhRMA Cert. Brief, at 4 (identifying physicians who treat a large number of diabetes patients); IMS Cert. Brief, at 3 (similar). A recent article by Sharona Hoffman illuminates some problems with pervasive use of health data in predictive analytics. Sharona Hoffman, Employing $E$ Health, 19 Kan. J.L. \& Pub. Pol'y 409 (2010). As Hoffman notes, electronic health records can be fed into "complex scoring algorithms" to "determine which individuals are likely to be high-risk and highcost workers." Id., at 422. It is not unrealistic for the state to be concerned that insurers, employers, and others will misuse the data to discriminate against certain towns or regions.

Respondents use prescriber-identifiable data without consent from either patient or physician, 
essentially forcing the doctor and their patients to speak against their will. The First Amendment requires no such thing. "The right to speak and the right to refrain from speaking are complementary components of the broader concept of 'individual freedom of mind.'" Wooley v. Maynard, 430 U.S. 705, 714 (1977) (citation omitted) (affirming the right to refrain from speaking). Vermonters are exercising "the right to be let alone," untroubled by data miners, echoing the sentiments of Justice Brandeis in his dissent in Olmstead v. United States, 277 U.S. 438, 478 (1928) ("the right to be let alone" is "the most comprehensive of rights, and the right most valued by civilized men").

A majority of this Court recently renewed attention in "a constitutional privacy 'interest in avoiding disclosure of personal matters." Nat'l Aeronautics and Space Admin. v. Nelson, 131 S. Ct. 746, 751 (2011) (citations omitted). Medical records are a particularly apt subject for careful protection of privacy and confidentiality, which in this case provides an appropriate constitutional counterweight to First Amendment concerns.

\section{B. The Prescription Confidentiality Law Fits Within The Established Frame- work Of State and Federal Privacy And Confidentiality Laws}

In the larger context of privacy statutes regulating access to information, the Vermont law is 
unremarkable. "In the United States legal landscape, sensitive information is accorded special recognition through a series of key privacy statutes ..." Helen Nissenbaum, Privacy as Contextual Integrity, 79 Wash. L. Rev. 119, 129 (2004) (listing statutory and common law privacy protections). One example in the business context includes laws protecting trade secrets. Neal M. Richards \& Daniel J. Solove, Privacy's Other Path: Recovering the Law of Confidentiality, 96 Geo. L.J. 123, 180-81 (2007) ("In many other contexts, such as trade secrets and business confidences, American law readily provides remedies against unwarranted breaches of trust."). In general, the American legal system protects trade secrets from public disclosure or private commercial use by others, absent consent or independent creation, as long as the trade secret owner takes reasonable means to protect the secret. Sharon K. Sandeen, Relative Privacy: What Privacy Advocates Can Learn from Trade Secret Law, 2006 Mich. St. L. Rev. 667, 698 (2006).

Respondents mischaracterize Section 17 as a ban on publication akin to "prohibit[ing] the Wall Street Journal from publishing stock prices." IMS Cert. Brief at 13. Interesting, but not relevant in the least to this appeal. If a rival firm obtained data mining files from one of the Respondents without consent and published it in The Wall Street Journal or sold it for commercial purposes, they would hear a great deal about the reach and power of copyright and trade secrecy law, despite the First Amendment. 
See e.g., Jerome Stevens Pharmaceuticals, Inc. v. Food \& Drug Admin., 402 F.3d 1249, 1250 (D.C. Cir. 2005) (suing the FDA for posting trade secrets on its website); In re Gabapentin Patent Litigation, 312 F.Supp.2d 653, 664 (D.N.J., 2004) ("The presence of trade secrets or other confidential information weighs against public access and, accordingly, documents containing such information may be protected from disclosure.") (citations omitted). When weighed against trade secrets, the "First Amendment typically does not afford the press any greater right to information than the general public." Id. at 664, n.6, citing Nixon v. Warner Communications, Inc., 435 U.S. 589, 609 (1978). See also Andrew Beckerman-Rodau, Prior Restraints and Intellectual Property: The Clash Between Intellectual Property and the First Amendment from an Economic Perspective, 12 Fordham Intell. Prop. Media \& Ent. L.J. 1, 5 (2001) ("[T]rade secrets, despite any expressive component, should be treated as property that falls outside the domain of the First Amendment. The very existence of a trade secret depends on maintaining its secrecy."). The First Amendment is not a defense to data theft.

As a publisher, amicus The New EngLand JourNAL OF MEDICINE owns trademarks and obtains copyrights to the articles they publish. If a rival firm steals entire articles, the JOURNAL will appropriately defend its intellectual property rights. The First Amendment does not block enforcement of the Copyright Act. "The press, like others interested in 
publishing, may not publish copyrighted material without obeying the copyright laws." Cohen v. Cowles Media Co., 501 U.S. 663, 669 (1991), citing Zacchini v. Scripps-Howard Broad. Co., 433 U.S. 562, 576-79 (1977) (television station is not permitted to broadcast an entire performance without consent); see also Rebecca Tushnet, Trademark Law as Commercial Speech Regulation, 58 S. Car. L. Rev. 737 (2007) (describing tensions between commercial speech and the Lanham Act).

The Respondents depend on these intellectual property and trade secrecy laws every day, and would not brook a First Amendment defense by an unauthorized user. See Richard A. Epstein, Privacy, Publication, and the First Amendment: The Dangers of First Amendment Exceptionalism, 52 Stan. L. Rev. 1003, 1006, 1035-46 (2000) (critical of First Amendment defenses against misappropriation of trade secrets).

Beyond the field of intellectual property, other laws restricting access to information do not derogate the First Amendment. "There are many federal provisions that forbid individuals from disclosing information they have lawfully obtained." Boehner $v$. McDermott, 484 F.3d 573, 578 (D.C. Cir. 2007) (listing many such examples, including grand jurors, court reporters, prosecutors, the Privacy Act, the Espionage Act, the Intelligence Identities Protection Act, tax return information, state motor vehicle records, Social Security Administration records, and attorneyclient privileges). 
Even our video store rental records are protected from disclosure by federal law. Video Privacy Protection Act of 1988, 18 U.S.C. $§ 2710$. The law forbids the knowing disclosure of "personally identifiable information" concerning these rentals. 18 U.S.C. $\S 2710$ (b)(1). If any person tried to sell or disclose this "personally identifiable information" without the consumer's consent or a statutory exception, they would violate federal law. 18 U.S.C. $§ 2710(d)$. No doubt this information could be commercially or politically valuable. This Court needs no reminder of the political use of "personally identifiable" video rental information. But that does not trigger First Amendment protection for the person who obtained it improperly or another downstream user or publisher who was complicit. "A direct solicitation of unlawful activity may of course be proscribed, whether or not it is commercial in nature." Lorillard Tobacco Co. $v$. Reilly, 533 U.S. 525, 579 (2001) (Thomas, J., concurring in part and concurring in judgment) citing Brandenburg v. Ohio, 395 U.S. 444 (1969) (per curiam). Even newspapers are subject to these rules:

It is, therefore, beyond dispute that "[t]he publisher of a newspaper has no special immunity from the application of general laws. He has no special privilege to invade the rights and liberties of others." Associated Press v. NLRB, 301 U.S., at 132-133, 57 S. Ct., at 655-656. Accordingly, enforcement of such general laws against the press is not subject to stricter scrutiny than would be 
applied to enforcement against other persons or organizations.

Cohen, 501 U.S. at 670 . "The press may not with impunity break and enter an office or dwelling to gather news." Id. at 669 .

The larger framework of privacy statutes operates generally untroubled by First Amendment concerns. As Judge Easterbrook said in Travis $v$. Reno, 163 F.3d 1000, 1007 (7th Cir. 1998), "No one thinks that the Privacy Act violates the first amendment. Well, maybe these plaintiffs $d o$ think this, but the position is untenable." (emphasis in the original). Likewise, the Court of Appeals for the District of Columbia said: "Aguilar stands for the principle that those who accept positions of trust involving a duty not to disclose information they lawfully acquire while performing their responsibilities have no First Amendment right to disclose that information." Boehner v. McDermott, 484 F.3d at 579 (referring to United States v. Aguilar, 515 U.S. 593, 605-06 (1995)).

Even in core First Amendment realms, privacy interests remain important. The Sixth Circuit held that a newspaper's First Amendment rights must be balanced against the financial privacy interests of innocent third parties. In re Knoxville News-Sentinel Co., 723 F.2d 470, 477 (6th Cir. 1983). The language in that case is similar to Vermont's declaration of a "reasonable expectation" of privacy, $2007 \mathrm{Vt}$. Acts \& Resolves No. 80 (Act 80) § 1(29):

These individuals possessed a justifiable expectation of privacy that their names and 
financial records not be revealed to the public. Their interests in privacy are sufficiently compelling to justify non-disclosure. United States v. Jenrette, supra, 653 F.2d at 620 (interest in avoiding injury to innocent third parties properly weighed against broadcasters' right of access); Application of Am. Broadcasting Cos., 537 F.Supp. 1168, 1172-73 (D.D.C.1982); Application of KSTP Television, 504 F.Supp. 360, 363 (D. Minn. 1980).

In re Knoxville News-Sentinel Co., 723 F.2d at 477. One key error in the Court of Appeals below was the failure to appreciate this difference between unauthorized access and subsequent publication. Publishers certainly have First Amendment rights, but not if the data was taken without consent, violating privacy, confidentiality, or intellectual property laws. Judge Livingston's dissent noted that Vermont carefully chose to protect confidentiality at a point in the process well before publication. Sorrell, 2010 WL 473183 at *17-18 ("because that first restriction prevents PI data from ever reaching the hands of plaintiff-appellants, the principal question to be resolved - and one the majority wholly overlooks is whether the restrictions on pharmacies implicates the First Amendment interests of the data miners and pharmaceutical companies before the Court.") (emphasis in original). As Judge Livingston further noted:

Vermont's law operates principally to prevent them from obtaining otherwise private 
PI data, and as such, does no more than restrict their unfettered access to information. This the First Amendment permits. See Zemel v. Rusk, 381 U.S. 1, 17, 85 S.Ct. 1271, 14 L.Ed.2d 179 (1965) (First Amendment "does not carry with it the unrestrained right to gather information").

IMS Health Inc. v. Sorrell, 2010 WL 473183 at *18 (Livingston, J. dissenting) (emphasis in original). Vermont protects private health information from unjustified invasion with a number of current laws, including the Vermont Patient Privilege Statute, Vt. Stat. Ann. tit. 12, § 1612; the Vermont Patient Bill of Rights, Vt. Stat. Ann. tit. 18, § 1852(7); and the Vermont Nursing Home Bill of Rights, Vt. Stat. Ann. tit. 33, § 7301. These laws protect the privacy of Vermont patients, giving them the freedom to keep their medical records confidential if they so desire:

The patient has the right to expect that all communications and records pertaining to his or her care shall be treated as confidential. Only medical personnel, or individuals under the supervision of medical personnel, directly treating the patient, or those persons monitoring the quality of that treatment, or researching the effectiveness of that treatment, shall have access to the patient's medical records. Others may have access to those records only with the patient's written authorization.

Vt. Stat. Ann. tit. 18, § 1852(a)(7) (the Vermont Bill of Rights for Hospital Patients). Nor is Vermont unique; 
similar medical privacy statutes are in force across the country. Center on Medical Record Rights and Privacy, Health Policy Institute, Georgetown University (2011), available at http://hpi.georgetown.edu/ privacy/records.html (listing medical privacy laws in all 50 states plus the District of Columbia). Regulating the practice of medicine has long been a traditional state function under the police power.

Respondents do not bring a preemption challenge to the Prescription Confidentiality Law because Congress has clearly protected medical privacy laws like Section 17. The HIPAA statute explicitly saves more stringent state privacy laws from preemption:

A regulation promulgated under paragraph (1) shall not supersede a contrary provision of State law, if the provision of State law imposes requirements, standards, or implementation specifications that are more stringent than the requirements, standards, or implementation specifications imposed under the regulation.

HIPAA § 264(c)(2). Vermont's more stringent privacy statutes are therefore expressly protected from preemption by federal law.

Under the HIPAA Privacy Rule, the federal government has identified no fewer than 18 sensitive data fields in medical records, and given these data fields special legal status as "protected health information" or "PHI." Id. Data fields such as the patient's 
name, social security number, address, and zip code (beyond the first three digits) are identified as PHI. Id. Improper disclosure of PHI violates federal law. Id. To our knowledge, no one has successfully brought a First Amendment challenge to GINA or the HIPAA Privacy Rule, but if Respondents have the constitutional right to commercialize prescriber-identifiable data without consent, it is hard to discern a meaningful distinction that would prevent commercialization of the medical data protected by GINA and HIPAA as well.

The federal government takes these medical privacy rights seriously. Indeed, just this year the Office of Civil Rights in the U.S. Department of Health and Human Services imposed two multimillion dollar fines for violations of the HIPAA Privacy Rule. Mary Anne Pazanowski, HHS Breaks New Ground With \$43 Million Penalty for HIPAA Privacy Rule Violation, 20 Health Law Reporter 277 (BNA) (Feb. 24, 2011) (penalizing Cignet Health of Prince George's County, Maryland, for "violating the rights of 41 patients"); Resolution Agreement, February 14, 2011, available at http://www.hhs.gov/ocr/ privacy/hipaa/enforcement/examples/massgeneralra.pdf (settlement in which Massachusetts General Hospital agreed to pay a penalty of $\$ 1$ million for accidentally leaving protected health information for 192 patients on a Boston subway train). Many other examples could be described. See, e.g., Charles Ornstein, ExWorker Indicted in Celebrity Patient Leaks Former Employee of UCLA Medical Center is Accused of Selling Data to the Media, L.A. Times, April 30, 2008; 
Joyce E. Cutler, Kaiser Permanente Gets \$187,000 Fine For Second Patient Privacy Violation, 18 Health L. Rep. 974 (BNA) (July 2009). Pharmacies have also been sanctioned for privacy violations. CVS Privacy Practices Need Investigation Despite FTC Order, Pharmacist Group Says, 18 Health L. Rep. 397 (BNA) (March 2009) (noting the FTC Consent Order with CVS Caremark Corp., one of the country's largest pharmacy chains).

Respondents' arguments, if successful, will destroy both federal and state medical privacy and confidentiality laws, commercializing the most intimate details of our medical histories, in a mistaken reliance upon the First Amendment.

\section{Consent For Limited Purposes Does Not Justify Commercial Data Mining}

In a strange twist, Respondents argue that the Vermont law doesn't do enough to protect privacy, as if they wished for a more comprehensive medical privacy law. IMS Cert. Brief at 2 ("Information relating to pharmaceutical prescriptions has long been widely distributed and used for numerous purposes."). Respondents mistakenly imply that medical privacy is somehow waived if the data is used for other limited purposes. PhMRA Cert. Brief at 9 ("Section 17 expressly permits speech based on prescriber history information for purposes of 'pharmacy reimbursement; prescription drug formulary compliance; patient care management; utilization review by 
a health care professional, the patient's health insurer, or the agent of either; or health care research'"). The Court of Appeals made similar observations. Sorrell, 2010 WL 4723183 at *5 ("The statute expressly permits the sale, transfer, or use of PI data for multiple other purposes"). The Court of Appeals treated these limited exceptions as if all physician privacy rights had been extinguished. Sorrell, 2010 WL 4723183 at *9 ("Physician privacy might be protected if the statute prohibited the collection and aggregation of PI data for any purpose, or if the use of such data were permitted in only rare and compelling circumstances.") The Court of Appeals goes on to say "[t]he statute at issue here, however, does not forbid the collection of PI data in the first instance." Id.

This is entirely mistaken, as "the record supports the conclusion that section 17 does not just reduce but dramatically reduces the spread of PI data." Sorrell, 2010 WL 4723183, at *29 (Livingston, J. dissenting). The plain text of the statute supports Judge Livingston. In the Prescription Confidentiality Law, Vermont articulated a "reasonable expectation" of privacy in prescriber-identifiable data:

Health care professionals in Vermont who write prescriptions for their patients have a reasonable expectation that the information in that prescription, including their own identity and that of the patient, will not be used for purposes other than the filling and processing of the payment for that prescription. Prescribers and patients do not consent 
to the trade of that information to third parties, and no such trade should take place without their consent.

2008 Vt. Acts \& Resolves No. 80, § 1(29). Vermont was even more explicit in Section 1(31): "This act is necessary to protect prescriber privacy by limiting marketing to prescribers who choose to receive that type of information," Act 80, § 1(31). For many years, the Vermont Bill of Rights for Hospital Patients has promised that "all communications and records pertaining to his or her care shall be treated as confidential" except for permitted uses such as treatment and insurance. Vt. Stat. Ann. tit. 18, § 1852(a)(7).

If the constitutionality of Section 17 hinges on the alleged lack of clarity in Vermont's statutes concerning privacy, then let this Court say so plainly. Vermont can then amend its laws to articulate additional statutory privacy rights and this litigation will commence again. But the Vermont Legislature has already spoken very clearly on this subject.

Of course, there are some important statutory exceptions to health privacy and confidentiality, primarily important government interests such as public safety and prevention of crime. Vt. Stat. Ann. tit. 18, § 4631(e)(5)-(6). In addition, protections can be waived by written consent. Vt. Stat. Ann. tit. 12, $\S 1612$ (a). Common reasons for granting consent include medical treatment, insurance reimbursement, and research. Anyone receiving health care in the 
U.S. in recent years will be familiar with these privacy consent forms.

But these consent forms are limited to particular purposes and do not otherwise destroy the private and confidential nature of the information. Disclosure might be permitted to the insurance company to facilitate paying the bills, but the insurance company cannot then publish the information on the Internet. The waiver was for a limited purpose and the information remains confidential. When someone tries to access PHI for another purpose, they suffer legal consequences, see supra pp. 19-20 (detailing HIPAA enforcement actions).

Pharmacies, health insurers and their intermediaries hold prescriber-identifiable medical records for limited purposes and subject to a duty to maintain confidentiality. These limited purposes include insurance reimbursement, filling prescriptions, scientific research, and the other exceptions described in subsection (e) of the Prescription Confidentiality Law. Vt. Stat. Ann. tit. 18, § 4631(e). No one has given permission for this data to be used for any other purpose. If a pharmacy sells this private health information to the data mining Respondents, Vermont law has been broken under the first sentence of $\S 4631(d)$. At that point, drug companies have no right to purchase this private health information and then hide behind the First Amendment. Nor is state action evident here: under Vermont law, the decision whether to share this information with data mining companies rests in the hands of the physician, not the state. 
The Vermont law is an integral part of a much larger legal landscape supporting the privacy and confidentiality of medical records. The Vermont law operates under an express preemption waiver under HIPAA, which explicitly permits states to enact more stringent medical privacy laws. Vermont has done so, with no more derogation to the First Amendment than any other privacy, trade secrecy or intellectual property law.

\section{THE SECOND CIRCUIT MISTAKENLY TREATED THE PRESCRIPTION CONFI- DENTIALITY LAW AS AN UNLAWFUL RESTRICTION ON SPEECH}

\section{A. Vermont Does Not Ban Drug Advertis- ing}

Respondents mischaracterize this case as commercial speech, hoping for First Amendment protection for their activities. But Section 17 does not ban advertising, which distinguishes this case from much of this Court's commercial speech jurisprudence. See Thompson v. W. States Med. Ctr., 535 U.S. 357, 360 (2002) ("We conclude, as did the courts below, that $\S 127(\mathrm{a})$ 's provisions regarding advertisement and promotion amount to unconstitutional restrictions on commercial speech, and we therefore affirm."); Lorillard, 533 U.S. at 562 ("the regulations prohibit advertising in a substantial portion of the major metropolitan areas of Massachusetts."); 44 
Liquormart, Inc. v. Rhode Island, 517 U.S. 484, 489 (1996) ("Our holding rests on the conclusion that such an advertising ban is an abridgment of speech protected by the First Amendment. ..."); Central Hudson Gas \& Elec. Corp. v. Public Service Comm'n of N.Y., 447 U.S. 557 (1980) ("This case presents the question whether a regulation of the Public Service Commission of the State of New York violates the First and Fourteenth Amendments because it completely bans promotional advertising by an electrical utility."); Va. State Board of Pharmacy v. Va. Citizens Consumer Council, 425 U.S. 748, 752 (1976) ("It is clear, nonetheless, that all advertising of such prices, in the normal sense, is forbidden."). For example, in Lorillard, Massachusetts directly regulated the placement of tobacco ads in stores. 533 U.S. at 562. Section 17 , by analogy, merely delegates to the storeowner the freedom to choose whether ads are appropriate. The heavy hand of the state is missing from Section 17.

Respondents also rely on Edenfield $v$. Fane, 507 U.S. 761, 770 (1990), see PhRMA Cert. Brief at 16, IMS Cert. Brief at 15, 22, but none of these cases involves publication of improperly obtained private information. In Edenfield, the statute at issue prohibited in-person solicitation by CPAs. If the Prescription Confidentiality Law prohibited in-person detailing by drug companies, then perhaps Edenfield would be directly relevant, but the Vermont statute does nothing of the sort. The result in Edenfield would have been quite different if that law had merely prohibited 
CPAs from using private, commercially valuable information taken without the consent of the client. For example, if a CPA tried to solicit new clients using the potential client's stolen credit card information, the First Amendment would stand aside when the state moved to stop this behavior.

The advertising ban cases should not be applied to overturn what is essentially a medical privacy law. Section 17 gives physicians the freedom to decide whether or not they will agree to share intimate details concerning their medical practices and patients with commercial data miners. That private decision is not a state-mandated ban on advertising.

\section{B. The Vermont Law - As Amended - Does Not Interfere With The "Marketplace of Ideas"}

Section 17's influence on the "marketplace of ideas" is not some heavy-handed pronouncement from the nanny state that regulates speech for drug detailing. Section 17 fosters private ordering with precious little state action. Physicians decide on their own what medical privacy practices are best for their patients. Section 17 simply gives physicians the freedom to protect medical privacy and confidentiality as they see fit.

The only provision of Vermont law challenged today is Section 17. IMS Health Inc., $2010 \mathrm{WL}$ 4723183 at * 1 . The original version of Section 17 also included a quite different provision in former Section 
4631(f) that directly regulated the content of speech by drug detailers when meeting with doctors and required detailers to provide state-approved evidencebased information in those promotional meetings. Section 17. In 2008, the Vermont Legislature repealed this provision in its entirety. $2008 \mathrm{Vt}$. Acts \& Resolves No. $89, \S 3$. The provision originally read:

(f) When a pharmaceutical marketer engages in any form of prescription drug marketing directly to a physician or other person authorized to prescribe prescription drugs as provided for under this section, the marketer shall disclose to the prescriber evidencebased information as provided for by rule describing the specific health benefits or risks of using other pharmaceutical drugs, including drugs available over the counter; which patients would gain from the health benefits or be susceptible to the risks described; the range of prescription drug treatment options; and the cost of the treatment options. As necessary, the office of Vermont health access, in consultation with the department of health, the area centers on health education, the office of professional regulation, and the office of the attorney general, shall develop rules for compliance with this subsection, including the certification of materials which are evidence-based as defined in Section 4621 of this title and which conditions have evidence-based treatment guidelines. The rules shall be consistent with the federal Food and Drug Administration's regulations regarding false and misleading advertising. 
To the extent practicable, the rules shall use the evidence-based standards developed by the blueprint for health.

2007 Vt. Acts \& Resolves No. 80, § 17(f) repealed by 2008 Vt. Acts \& Resolves No. 89, §3. The Court of Appeals failed to fully consider the implications of this repeal. For example, much is made of Vermont's proclaimed intervention into the "marketplace of ideas," Act $80, \S 1$, and "ensuring prescribers receive unbiased information," Section 17. IMS Health Inc., 2010 WL 4723183 at *4-5 ("The findings expressly state the legislature's intent to interfere with the marketplace of ideas to promote the interests of the state."). The Court of Appeals went on at length:

The legislature expressed its concern that the "marketplace for ideas on medicine safety and effectiveness is frequently one-sided," leading doctors to prescribe "drugs based on incomplete and biased information." Id. at $\S 1(4)$. The legislature therefore found that "[p]ublic health is ill served by the massive imbalance in information presented to doctors and other prescribers." Id. at $\S 1(6)$. Section 17 is the state's attempt to correct what it sees as an unbalanced marketplace of ideas that undermines the state's interests in promoting public health, protecting prescriber privacy, and reducing health care costs.

IMS Health Inc., 2010 WL 4723183 at *5. Reliance on these legislative findings in Act 80, §§ 1, 17 to support 
a First Amendment challenge is misguided at best, as many of the findings relate to the now-repealed version of Section 4631(f). And yet, Respondents cite these irrelevant legislative findings incessantly, see IMS Cert. Brief at 1, passim; PhRMA Cert. Brief at 1, passim. The Respondents have made an interesting hypothetical argument that former Section 4631(f) might be unconstitutional, but that provision is not part of Vermont's law.

In addition, some of the other legislative findings quoted by Respondents are not relevant for a different reason. Many of the legislative findings relate to other provisions in Act 80 that Respondents have not challenged, and yet they mix-and-match in an attempt to infer guilt by association. The unchallenged sections of Act 80 include many provisions that address the allegedly biased nature of information in drug sales and represent Vermont's attempt to intervene in the market to reduce prescription drug prices. See, e.g., the Pharmacy Best Practices and Cost Control Program (establishing a program to "reduce the cost of providing prescription drugs," including an "evidence-based preferred list of covered prescription drugs that identifies preferred choices within therapeutic classes for particular diseases and conditions, including generic alternatives and over-the-counter drugs."); revisions to Vermont's Pharmaceutical Marketing Disclosure Law; mandatory disclosure of the actual price of prescription drugs dispensed in Vermont; the creation of state pharmacy discount plans; regulation of pharmacy benefit managers; notice requirements for changes in preferred drug 
lists; a state supported evidence-based education program; a generic drug voucher pilot project; expanding the use of lower priced prescription drugs under the federal 340B program; an annual fee on drug companies, used to fund the evidence-based education programs described above; consumer protections against drug advertisements that do not comply with federal laws; and related insurance marketing reforms, Act 80, §§ 3-9, 11, 14-16, 20-22.

Respondents should stop quoting legislative findings in Act 80, $\$ 1$ that refer to unchallenged legislation unless it references the specific language in Section 17, as amended. Perhaps one day Respondents can argue that these other provisions in Act 80 are unconstitutional, but today is not that day.

\section{Medical Privacy Is A Substantial State Interest}

With respect to privacy, the Court of Appeals improperly conflated the first and second prongs of Central Hudson, 447 U.S. at 566. The first prong is satisfied because medical privacy is undeniably a substantial state interest. Supra §§ I.A. - B. In Trans Union, financial privacy was found to be a substantial state interest, Trans Union Corp. v. Fed. Trade Comm'n, 245 F.3d 809, 818 (D.C. Cir. 2001) ("Contrary to the company's assertions, we have no doubt that this interest - protecting the privacy of consumer credit information - is substantial."). The state interest in medical privacy is even more clear, given the 
sustained interest in medical privacy at the state and federal levels, supra, §§ I.A. - B.

When Judge Koeltl dismissed the privacy argument as "speculative," Sorrell, 2010 WL 4723183 at $* 10$, this is best understood as a claim that Vermont has not proved the third prong - in this case, whether Section 17 "directly advances the governmental interest asserted," Central Hudson, 447 U.S. at 566. Hence, Judge Koeltl was actually operating under the second prong when he wrote, "Vermont has not shown any effect on the integrity of the prescribing process or the trust patients have in their doctors from the use of PI data in marketing." Sorrell, 2010 WL 4723183 at $* 10$.

The First Circuit found the goal of cost containment to be sufficient, and did not fully take up the issue of privacy. Ayotte, 550 F.3d at 84. In the Maine data mining case, the District Court held that "patient confidentiality is a substantial government interest," IMS Health Corp. v. Rowe, 532 F.Supp.2d 153, 170 (D. Me. 2008), but the Attorney General of Maine did not extensively argue the Maine Legislature's findings on prescriber privacy. Id. at 170-72. Similarly, in this case, the trial court below reached its decision on other grounds and did not fully consider privacy. As the District Court below said:

Because the Court accepts cost containent and protecting public health as subtantial government interests, it need not consider the Attorney General's assertion that protecting prescriber privacy is also a 
substantial government interest. Cf. Ayotte, 550 F.3d at 55 (restricting analysis to cost containment interest for "simplicity's sake"); Anderson, 294 F.3d at 461 (declining to consider an asserted interest because the regulatory scheme was sustainable based on another interest).

IMS Health Inc. v. Sorrell, 631 F.Supp.2d 434, 450 (D. Vt. 2009) (App.68a-118a). If this Court finds Vermont's privacy interests to be insufficiently articulated during litigation, we urge this Court to remand this case back to the trial court to develop a full record on the privacy interests advanced by Section 17 .

\section{The Prescription Confidentiality Law "Directly Advances" Substantial State Interests}

Vermont is entitled to protect privacy qua privacy, not as a means to whatever social ends Judge Koeltl finds sufficiently meritorious. For example, the Fair Credit Reporting Act easily survived a First Amendment challenge in 2001, even though it flatly prohibited the sharing of some types of data. Trans Union, 245 F.3d at 818 ("Trans Union's First Amendment challenge fares no better. Banning the sale of target marketing lists, the company says, amounts to a restriction on its speech subject to strict scrutiny. Again, Trans Union misunderstands our standard of review."). The Trans Union court did not require that the Fair Credit Reporting Act directly 
advance financial well-being, economic efficiency, or some other judicially-selected goal. Directly advancing financial privacy was enough.

It should be enough that the Prescription Confidentiality Law was supported by an unanimous resolution from the Vermont Medical Society: "the use of physician prescription information by sales representatives is an intrusion into the way physicians practice medicine." JA376-78, at 378. This Resolution also stated: "the doctor-patient relationship requires confidentiality and privacy to work effectively." JA376. Just as the state helped create this hazard by requiring the maintenance of prescriber records at Vermont pharmacies, Pet. Br. at 3-5, JA253, it is entitled to mitigate it by limiting the use of these records.

Vermont's law vindicates other longstanding dimensions of health privacy. Rarely does a month go by without a revelation of a data breach, see supra pp. 19-20. In a world where privacy is daily being eroded by technological advances, Vermont may deem it prudent to slow the dissemination of certain data in order to avoid similar breaches. Federal law has specifically permitted just such a move. HIPAA $\S 264(\mathrm{c})(2)$.

Vermont's concerns about data mining are well founded. The Respondents cannot plausibly deny that visits from sales representatives armed with prescriber-identifiable data exert a powerful influence on physicians' prescribing practices. Indeed, that is the 
foundation of this multi-billion dollar business model. App.71a; JA169; A-168. Before the First Circuit, "[t]he plaintiffs did not deny that prescribing histories made detailing more efficacious." Ayotte, 550 F.3d at 56 .

\section{Data Mining Increases Costs}

The medical literature confirms this pervasive influence. Many peer-reviewed studies have demonstrated the substantial effect that detailing has on physician prescribing practices. An extensive record was developed at trial, JA145-46, 149, 156-58, 160-62, 164-65, 325-28, 366, 376, 469, 473, 481-83, 488-90, $494-95,510,525$. In addition, the peer-reviewed literature is extensive, see, e.g., Ray Moynihan, et al., Selling Sickness: The Pharmaceutical Industry and Disease Mongering, 324 BMJ 886 (2002); Katia Campo, et al., Physicians' Decision Process for Drug Prescription and the Impact of Pharmaceutical Marketing Mix Instruments, 22 Health Market. Quarterly 73 (2005); Puneet Manchanda \& Elisabeth Honka, The Effects and Role of Direct-to-Physician Marketing in the Pharmaceutical Industry: An Integrative Review, 5 Yale J. Health Policy, Law \& Ethics 785 (2005); Ashley Wazana, Physicians and the Pharmaceutical Industry: Is a Gift Ever Just a Gift?, 283 JAMA 373 (2000); Nicole Lurie, et al., Pharmaceutical Representatives in Academic Medical Centers, 5 J. Gen. Internal Med. 240 (1990); Michael A. Steinman, et al., Characteristics and Impact of Drug Detailing for Gabapentin, 4 PLoS Med. 743 (2007); 
Eric G. Campbell, et al., A National Survey of Physician-Industry Relationships, 356 New Eng. J. Med. 1742 (2007). In short, detailing sells drugs. As the District Court noted:

This is the strongest evidence of the important role of PI data in pharmaceutical detailing. Put simply, if PI data did not help sell new drugs, pharmaceutical companies would not buy it.

IMS Health Inc., 631 F.Supp.2d at 451.

\section{Data Mining Promotes Unsafe Drugs}

Data mining also raises safety issues. Off-label promotion is a safety issue because the FDA has not approved the drug as safe and effective for the unapproved "off-label" use. Data mining is used extensively in off-label promotion, resulting in many lawsuits and enforcement actions against patent-based drug companies. Aaron S. Kesselheim \& David Studdert, Whistleblower-Initiated Enforcement Actions Against Health Care Fraud and Abuse in the United States, 1996 to 2005, 149 Annals Int. Med. 342 (2008); Michelle M. Mello, et al., Shifting Terrain in the Regulation of Off-Label Promotion of Pharmaceuticals, 360 New Eng. J. Med. 1557,1562-63, Table 2 (2009). Pfizer, a member company of Respondent PhRMA, recently agreed to plead guilty to off-label promotion of prescription drugs and pay a $\$ 2.3$ billion fine. Jonathan D. Rockoff \& Brent Kendall, Pfizer to Plead Guilty to Improper Marketing, Wall St. J., Sept. 3, 2009. 
Prescriber-identifiable medical records were used to facilitate off-label promotion of gabapentin (Neurontin). C. Seth Landefeld \& Michael A. Steinman, The Neurontin Legacy - Marketing Through Misinformation, 360 New Eng. J. Med. 103 (2009). Significant budgets were allocated for detailing and promotion to physicians who were high prescribers of gabapentin. Michael A. Steinman, et al., Narrative Review: The Promotion of Gabapentin: An Analysis of Internal Industry Documents, 145 Annals Int. Med. 284, 287, Table 2 (2006). High prescribers are identified through data mining. Id., JA325, 481-82, 525.

Prescriber-identifiable medical records were used to facilitate off-label promotion of Xyrem, a drug approved for narcolepsy. The physician responsible for the off-label promotion was recruited by a detailer who "had noticed Gleason's high prescription rate for Xyrem in 2003 and hired him to give speeches and visit other physicians to discuss off-label uses of the drug." Mello, et al., Shifting Terrain, at 1561.

Prescriber-identifiable medical records were also used to promote rofecoxib (Vioxx). Data mining allowed Merck to target specific physicians for detailing based on their prescription history. Litigation following the withdrawal of rofecoxib has revealed the existence of elaborate sales training campaigns conducted by Merck (a member of the PhRMA Respondent) to divert attention away from concerns about the cardiac risk posed by the drug during these detailer/physician meetings. See Aaron S. Kesselheim 
\& Jerry Avorn, The Role of Litigation in Defining Drug Risks, 297 JAMA 308 (2007).

Three additional examples of data mining-related safety problems are nesiritide (Natrecor), Eric J. Topol, Nesiritide - Not Verified, 353 New Eng. J. Med. 113 (2005), Aaron S. Kesselheim, et al., The Rise and Fall of Natrecor for Congestive Heart Failure: Implications for Drug Policy, 25 Health Affairs 1095 (2006); ezetimibe (Zetia); and a combination of this drug with simvastatin (simvastatin/ezetimibe or Vytorin), Cynthia Jackevicius, et al., Use of Ezetimibe in the United States and Canada, 358 New Eng. J. Med. 1819 (2008).

\section{Section 17 Gives Vermont Physi- cians The Freedom To Opt Out Of Data Mining}

It should be noted that Vermont physicians cannot otherwise prevent the sale of their confidential information to data miners because they lack privity with the pharmacies and data intermediaries who sell the data. Sorrell, 2010 WL 4723183 at *17 (describing the creation of prescriber-identifiable data "without the knowledge or permission of the doctor, let alone the patient") (Livingston, J., dissenting); IMS Health, 631 F.Supp.2d at 456-57 (describing the "three-step transaction" to create data mining); JA253-54; see also, Daniel J. Solove, Identity Theft, Privacy, and the Architecture of Vulnerability, 54 Hastings L.J. 1227, 1260 (2003) ("Much of a person's 
sensitive information is not exclusively in the hands of that person - it is in the hands of various companies. Some are companies that a person does business with, such as financial institutions and utility companies. But others are ones that gather data about people without their knowledge and consent.").

The alternative process offered by the American Medical Association is unsatisfactory because only 5\% of Vermont physicians are members of the AMA. JA402-03. Furthermore, the AMA process does not forbid data mining, only the use of the AMA Physician Masterfile, for which the AMA earns millions in royalty income from the data miners. The Prescription Project, Prescription Data Mining, at 3 (Nov. 19, 2009), available at http://www.prescriptionproject.org/ tools/initiatives_factsheets/files/0004.pdf ("The response of the American Medical Association (AMA) to concerns about datamining has been weak. The AMA plays a key role in enabling the data-mining industry by selling its physician database to data-mining companies.... Sale of Masterfile data brought the AMA $\$ 44.5$ million in 2005. Although the AMA initiated an option in 2006 to allow physicians to "opt out" of this program, the process is cumbersome and few physicians are aware of the option. Moreover, even when a doctor "opts out," the AMA continues to sell that doctor's personally identifiable prescribing information. Pharmaceutical companies may still use the information to target their marketing efforts, as long as they pledge not to provide that individual 
prescriber's data directly to salespeople. Furthermore, the collection of prescribing data and identities through pharmacies is not affected by the AMA policies.").

Respondents suggest that doctors could just forego detailing altogether, PhRMA Cert. Brief at 5, but in the view of many physicians that solution throws the baby out with the bathwater since a meeting with detailers can bring some benefits to the physician's patients, including free samples for uninsured patients. JA411-12. "Many physicians thus tolerate detailing visits in order to reap the harvest of samples," Ayotte, 550 F.3d at 46 ("The free samples, however, are highly prized.") The most narrowly tailored and freedom-enhancing mechanism is to permit the physician to choose a middle course, detailing without data mining.

\section{E. Vermont Left This Complex Medical Decision In The Hands Of The Treat- ing Physician}

Amici have significant expertise in the evaluation of peer-reviewed medical evidence. While the empirical evidence against data mining is significant, Vermont did not choose to ban it outright or to directly regulate detailers' speech. Instead, Vermont promoted freedom by giving physicians the ability to evaluate the evidence themselves and then choose whether or not to participate in data mining. This promotes First Amendment values, favoring a 
distributed model of scientific evaluation over a hierarchical decision-making structure.

Respondents attack Vermont's legislative findings as being insufficiently voluminous, Brief of Appellant PhRMA before the Second Circuit at 21-22, while simultaneously offering their experts to say that Vermont made a policy mistake. Respondents presented much of this evidence to the Legislature in hearings, and in many formal and informal meetings with their lobbyists. No complaint has been lodged concerning voting fraud or irregularity in legislative procedure. Indeed, Respondents concede that the Prescription Confidentiality Law was legally approved by both the House and Senate in Vermont and signed by the Governor. Brief of Appellant PhRMA before the Second Circuit at 22. At the end of the process, the duly-elected representatives of Vermont disagreed with the Respondents and created the Prescription Confidentiality Law. Respondents ask this Court to ignore the democratic process in Vermont, and take Respondents' side in many complex health policy issues such as the efficacy of various prescription drug cost saving measures, drug safety issues, and the wisdom of expanding privacy protections to prescriberidentifiable medical records. The Vermont law wisely leaves these decisions in the hands of the doctor.

Furthermore, the cases cited in Respondents' briefs generally relate to legislative determinations in an area where the government doesn't have particular expertise, such as alcohol, tobacco and pharmacy advertising and solicitations by CPAs and in-home real estate agents. Here, Vermont does not just have 
an opinion on data mining; they have years of direct experience, with billions of dollars in health care costs provided by and through the State. If Respondents have winning policy arguments, let them make those arguments to the people paying the bills and to the physicians seeing patients. Apparently, they lost those arguments, which sends them to this Court, looking for a third or fourth bite of the apple.

Finally, unlike some cases where a court is forced to evaluate scientific evidence, this Court is not required to do so today. Leave these complex matters of science and health policy in the hands of those best suited to make the decision - the prescribing physicians who are able to discuss these issues with their patients. Let the individual physician decide whether data mining is detrimental or helpful. The First Amendment does not require unconsented disclosure of prescriber-identifiable medical records. 


\section{CONCLUSION}

The Court should reverse the Court of Appeals' decision and direct entry of judgment for the Petitioner.

Respectfully submitted,

Michael Kevin OutTerson

Counsel of Record for the Amici Curiae

Boston University SchoOL OF LAW

765 Commonwealth Ave.

Boston, MA 02215

(617) 353-3103 